\title{
Biography of Professor Sarel Jacobus van der Merwe
}

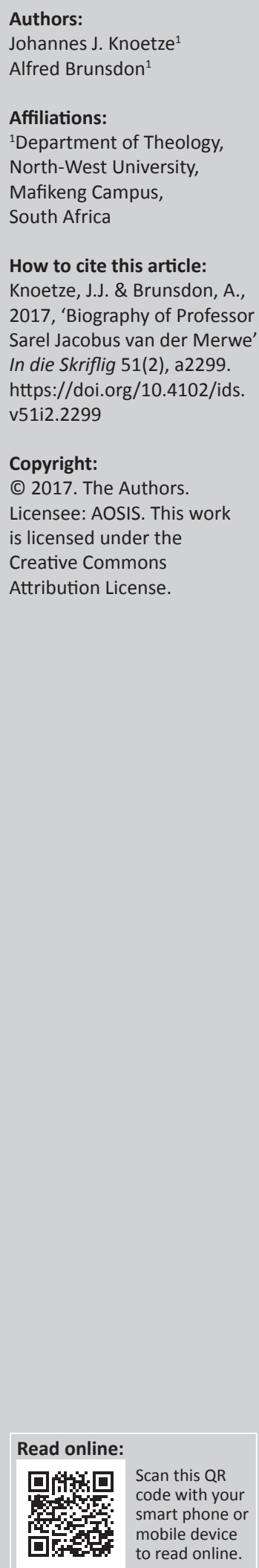

\section{Introduction}

It was indeed an honour to compile the biography of our friend and colleague, Professor Sarel van der Merwe for the festschrift, which commemorates his life and academic career. Because we have had the privilege of working closely with him for a couple of years, this biography will lay no claim to being largely objective. It is more of a personal document comprising facts we have gleaned from his biography, combined with our personal observations as well as those of other colleagues. We trust that it will provide the reader with a true reflection of his life and work, but also pay a fitting homage to his distinguished career.

\section{Early life, calling and studies}

Sarel was born on 1 November 1948, the fifth child of Demps and Annie van der Merwe in Pietersburg (now Polokwane). Some of his first childhood memories were that of his missionary father who served in the then South-West Africa (Namibia) and who later became Professor of Missiology at the Theological School in Potchefstroom. After completing his secondary schooling at Potchefstroom Gymnasium, he heeded his own calling to ministry by enrolling at the Potchefstroom University for Christian Higher Education in 1968 where he obtained his Baccalaureus Artium in 1970, with Philosophy and Logic as majors. In the ensuing years, he furthered his studies at the Potchefstroom Theological School and obtained the degree Theologiae Baccalaureus in 1974, together with the candidate's certificate for ministry, which qualified him to be ordained as minister in the Reformed Churches of South Africa.

\section{Congregational ministry and early academic career}

Sarel was ordained as minister of the Reformed Churches in South Africa in Namibia in 1975, where he served the congregations of Keetmanshoop and Karasburg in tandem until 1978. In the latter part of the same year, he returned to South Africa to become minister and missionary at the Reformed Church of Kuruman where he remained until 1982. He was also called in 1982 to serve as missionary amongst the Tswana-speaking people in the congregation of Duineveld, situated at Hotazel in the Kudumane district.

It was during this period that Sarel decided to further his studies in Theology, which resulted in obtaining the Theologiae Magister in 1987 (cum laude) and the Philosophiae Doctor in Missiology during 1993. The topic of his master's research focused on a missiological assessment of the dramatisation of biblical material as method for mission and his doctoral study on a foundational assessment of radio and television as missionary medium in South Africa.

Shortly after obtaining his master's degree, Sarel became actively involved in the training of ministers as part-time lecturer at the Sekolo sa Mojadi ${ }^{1}$ in Mareetsane, a mission project of the Gereformeerde Gemeenten in the Netherlands, aimed at the training of evangelists for mission work under the Tswana-speaking people. ${ }^{2}$ With the dawn of the new democracy in 1994, a host of changes took place in higher education and would eventually have an impact on Sarel's academic career. One of them was the closing of the Hammanskraal Theological Seminary, where black ministers of the Reformed Churches of South Africa received training. Subsequently, the Faculty of Theology in Potchefstroom sought partnerships with theological colleges to present their programmes. This resulted in a partnership between the Faculty of Theology in Potchefstroom and the Sekolo sa Mojadi to present a degree programme of the Faculty on their premises. To facilitate this partnership, the Faculty in Potchefstroom accredited the staff of the Sekolo sa Mojadi

\section{A Tswana expression meaning 'School of the Sower'.}

2.For a detailed account of the history of the Sekolo sa Mojadi, see Brunsdon, A. \& Van der Merwe, J.S., 2013, 'From Mojadi to Mafikeng: Notes on the newfound Department of Theology', Studia Historiae Ecclesiasticiae 39(1), 295-313. 
in 1996 and the name of the Sekolo sa Mojadi was changed to College ya Mojadi. Sarel's academic responsibilities multiplied as he was now an accredited lecturer of the Faculty of Theology. He also became involved in the development of a three-year BA degree in Theology and the development of study material, given that the College ya Mojadi was more in the need of a bachelor's degree than the seven-year qualification offered by the Faculty of Theology. Sarel also became the principal of the college, a position which he would be responsible for until 2005.

Another important change that took place that would influence Sarel's academic career was the merger between the Potchefstroom University for Christian Higher Education, the University of the North-West in Mmabatho and the Vista University in Sebokeng in 2004 to form the current North-West University. This presented an opportunity for the Faculty of Theology in Potchefstroom to consider the possibility of an official Department of Theology on the Mafikeng Campus of the new merger university.

\section{Full-time academic career and the establishment of the Department of Theology on the Mafikeng Campus of the North-West University}

As Sarel, through his involvement at the College ya Mojadi, was already familiar with the facilitation of the academic programmes of Potchefstroom, he became a strategic partner for the realisation of a Department of Theology on the Mafikeng Campus. A decade after being accredited as lecturer at the previous Potchefstroom University for Christian Higher Education, he was thus appointment as associate professor in Missiology on the Potchefstroom Campus (2006) of the North-West University with the task of initiating a Department of Theology at Mafikeng. In a true pioneering spirit, Sarel accepted the challenge and moved from Hotazel to Mafikeng. He went on to manage the process of launching a programme in Theology on the Mafikeng Campus, as well as undertaking the many negotiations with campus management that led to the official establishment of the Department of Theology in Mafikeng in 2011, as a department within the Faculty of Human and Social Sciences.

While this may have been a life-time achievement for him, it also changed the course of his personal academic path. Due mainly to this fact, since 2006 Sarel single-handedly managed the establishment of the new department, all teaching responsibilities as well as all administrative duties. Understandably, this absorbed most of his personal and academic energy, which denied him privileges such as taking research leave and attending conferences on a regular basis. Adding to this, lectures for the growing number of students were presented after hours, keeping Sarel in his small corner office of the base-building and the adjacent classroom until the late hours of the evening. It was only during 2010 that
Sarel was afforded the privilege of part-time assistance in the form of part-time lecturers to ease the teaching and learning responsibilities. Despite this heavily laden programme, Sarel, however, still managed to occasionally present academic papers at conferences and publish some of his research.

Since the inception of the department, Sarel thus focused on teaching, administration and management of the Department as programme leader. He also invested time in the supervision of post-graduate students on the Potchefstroom Campus, as well as students who furthered their studies on the Mafikeng Campus. The Department grew and two permanent staff members were appointed in 2012, under his guidance, which grew to four permanent staff members in 2017.

Sarel also carried the torch for Theology as ambassador of the programme while engaging many different forums in the wider campus life and community. He duly earned the respect of campus management by being tasked to act as School Director of the School of Human Sciences from August 2013 until his retirement at the end of 2014. Although this was a taxing task, Sarel made a visible impact as reflected in increased research outputs of staff during that period.

At the end of 2014, Sarel reached the mandatory age of retirement for North-West University staff. Affectionately known and respected as the 'Father of Theology' on the Mafikeng campus, Sarel then reluctantly exchanged his office on campus for his office at home, from where he still actively provides supervision to numerous post-graduate students and also still invests time in the interest of the Department. He currently continues his love for teaching via the Unit for Open Distance Learning, where he facilitates an Old Testament module for the Honours programme.

\section{Church involvement and community engagement}

Apart from serving the congregations mentioned, Sarel made a continuous and meaningful contribution to the broader community of the Reformed Churches of South Africa throughout his academic career. This is especially evident from his role as elected chairperson at regional and national church assemblies on many occasions. He acted as leader of numerous deputy groups of the church that studied, amongst others, social problems and church doctrine. He also served for a couple of years as member of the Curators of the Reformed Churches of South Africa, whose task it is to oversee the training of ministers of the Reformed Church.

Since he resided in Mafikeng, Sarel also accepted responsibility to pastor the Reformed Congregation in Mafikeng, which included conducting sermons in Mafikeng as well as in the neighbouring Botswana. This implied travelling vast distances on Sundays before resuming his academic duties on Mondays. In this way, he remained in touch with congregational ministry, which was important to 
him for the sake of the ministerial development of his students.

Being a missionary at heart, Sarel's impact through his life-long commitment to community engagement was tremendous. The establishment of HIV and AIDS programmes in several rural villages were of special interest to him. He also showed a keen interest in the empowerment of the youth of all cultures to become self-sufficient and evade poverty. Sarel managed a feeding scheme for many years, in aid of the poorest of the poor, which remains active to this day. Together with the Reformed Congregation Uitkyk, he is involved in the establishment of gardens in informal settlements, where the poor is assisted and encouraged to grow their own fruit and vegetables in the interest of a nutritious diet.

As part of his community engagement, he built enduring relationships with the local pastors of Mafikeng and the surrounding communities. In this capacity, he facilitated pastor-conferences on a regular basis, where he invested time and effort in equipping theological pastors in Mafikeng. At the same time, the work of the Department was advertised and over time this became a novel way of recruiting new students.

\section{Family and personal life}

From the beginning of his career as minister and academic, Sarel was selflessly supported by his wife Belia (born Booyens) whom he met during his studies and married in 1974. Belia, who also holds a PhD in Afrikaans literature, soon learnt to support her ever-travelling spouse, investing most of her time and energy in rearing their three children, Danie, Kobus and Joanette.

Sarel and Belia are currently blessed with six grandchildren of whom they are extremely fond and on their behalf, they travel extensively to support and enjoy the development of their grandchildren. The couple was also recently done proud by their daughter Joanette obtaining her PhD in Linguistics and Literary Theory.

Spending a great deal of time in Namibia, Sarel nurtured two hobbies of which he grew particularly fond, namely hunting and flying. While the first was for pure enjoyment, the latter was born from practical considerations regarding the long distances he needed to travel as part of his ministry.
Sarel therefore qualified himself as a light aircraft pilot and acquired his own aircraft. Over the years he became an experienced pilot and even survived at least one emergency landing in the execution of his duties as minister. Today he still enjoys this hobby with his sons, who both share his love for flying. Being fond of competitive flying, Sarel regularly competes in the annual President's Cup Air Race. Together with Mike Howell, Sarel won this event in 1995 and during 2016, Sarel and his son Kobus were runners-up of this prestigious event.

\section{Impact and legacy}

Because Sarel's first passion was the teaching and mentoring of students, the impact he made is to be sought in the lives of his students. Many of the students who applied for studies at the Department came from challenging backgrounds. As programme leader, Sarel was the first person they met. If students were convinced about their calling to ministry, Sarel was committed to assist them, even if it meant sacrificing his personal resources. One such testimony relates to a student who wrote a personal tribute to Sarel shortly after Sarel's retirement. ${ }^{3}$ In his tribute, he calls Sarel 'God's messenger, a father and mentor'. We take the liberty of quoting the next passage from his tribute, with his permission, as it best illustrates to a degree the impact Sarel has made on his life (sic):

As I pay tribute to Prof. Sarel van der Merwe, it won't be complete if I do not mention that I only paid R75.00 for my entire academic life. The rest of the tuition was sponsored. Until today I don't know who did that. I never asked, but he always gave me my registration certificates. I have a library now which can be classified as an academic one due to his generosity and caring. I have managed to go through life by his guidance and care.

The legacy that Sarel leaves behind is thus a living one, demonstrated in the lives of the students for whom he made it possible to study Theology and to pursue the calling they received from God. Of course, his legacy ultimately lives in the Department of Theology on the Mafikeng Campus, which owes much of its existence to a man who truly embodied the missio Dei in his life as minister, missionary and academic.

3.Tribute written by Dr. Phemelo Marumo, first PhD graduate of the Department of Theology and currently lecturer in the School of Philosophy of the Faculty of Human and Social Sciences on the Mafikeng Campus. 